\title{
KOSZTY UZYSKANIA PRZYCHODÓW \\ W PODATKACH DOCHODOWYCH OD OSÓB FIZYCZNYCH I PRAWNYCH - SPECYFICZNA KLAUZULA GENERALNA CZY DEFINICJA LEGALNA?
}

\section{UWAGI WSTĘPNE}

Unormowane w ustawach o podatku dochodowym od osób fizycznych oraz podatku dochodowym od osób prawnych koszty uzyskania przychodów od wielu lat w licznych wyrokach zarówno wojewódzkich sądów administracyjnych, jak i Naczelnego Sądu Administracyjnego, a także w orzecznictwie administracyjnym organów podatkowych i piśmiennictwie podatkowym określane bywaja mianem „specyficznej klauzuli generalnej”. Owo uzupełnienie nazwy własnej kategorii prawnej, jaka jest klauzula generalna, przymiotnikiem „specyficzna” lub „swoista” wskazywać może na to, że zarówno w opinii polskiej judykatury, organów podatkowych, jak i niektórych przedstawicieli doktryny rozróżniać należy na gruncie prawa podatkowego „specyficzne klauzule generalne” i „niespecyficzne klauzule generalne”. Podkreślić należy, że takiego rozróżnienia terminologicznego nie ma ani w piśmiennictwie teoretycznoprawnym, ani w publikacjach dogmatycznych z zakresu innych dyscyplin prawa. Jedyna znana w piśmiennictwie specyfikacja tego rodzaju zwrotu nieostrego ocennego polega na rozróżnieniu klauzul generalnych i klauzul generalnych odsyłających ${ }^{1}$.

W związku z tym, że koszty uzyskania przychodów bywają również w judykaturze i literaturze naukowej określane mianem definicji legalnej, zasadne wydaje się jednoznaczne ustalenie tego, jaka kategoria prawna jest ten niezwykle ważny element techniczny konstrukcji obydwóch podatków dochodowych w Polsce.

\section{KIERUNKI INTERPRETACJI ZWROTU PRAWNEGO „KOSZTY UZYSKANIA PRZYCHODÓW”}

Zgodnie z treścią ustawy o podatku dochodowym od osób fizycznych ${ }^{2}$ oraz ustawy o podatku dochodowym od osób prawnych ${ }^{3}$ kosztami uzyskania

\footnotetext{
${ }^{1}$ Zob. Leszczyński (2000): 23-24; (2001): 27-35.

${ }^{2}$ Zob. art. 22 ust. 1 ustawy z 26 lipca 1991 r., o podatku dochodowym od osób fizycznych, t.jedn.: Dz. U. 2019, poz. 1387 (dalej jako: u.p.d.o.f.).

${ }^{3}$ Zob. art. 15 ust. 1 ustawy z 15 lutego 1992 r. o podatku dochodowym od osób prawnych, t.jedn.: Dz. U. 2019, poz. 865 ze zm. (dalej jako: u.p.d.o.p.).
} 
przychodów są koszty poniesione w celu osiagnnięcia przychodów lub zachowania albo zabezpieczenia źródła przychodów z wyjątkiem kosztów wymienionych $\mathrm{w}$ odrębnych przepisach obydwóch ustaw ${ }^{4}$. Uzupełnieniem powyższych regulacji sa niezwykle rozbudowane kazuistyczne katalogi imiennie nazwanych wydatków, uznanych przez ustawodawcę ex lege za koszty uzyskania przychodów ${ }^{5}$.

Wykładnia językowa przywołanych przepisów prowadzi do konstatacji, że warunkiem uznania danego wydatku za koszty uzyskania przychodów jest zaistnienie dwóch łącznych przesłanek, w myśl których:

- poniesiony wydatek powinien być dokonany w celu osiagnięcia lub zachowania albo zabezpieczenia źródła przychodów oraz

- poniesiony wydatek nie może być zaliczony do katalogu negatywnego, obejmującego tzw. wydatki niepotrącalne ${ }^{6}$.

Natomiast analiza orzecznictwa i piśmiennictwa wskazuje na następujące kierunki interpretowania tytułowego pojęcia prawnego jako kategorii prawnej. Po pierwsze, zarówno w judykaturze ${ }^{7}$, jak i w indywidualnych interpretacjach podatkowych ${ }^{8}$ oraz $\mathrm{w}$ literaturze przedmiotu ${ }^{9}$ koszty uzyskania przychodów uznawane sa za „swoistą klauzulę generalną”. Wskazać można także nieliczne wyroki ${ }^{10}$ i publikacje ${ }^{11}$, w których koszty podatkowe uznawane sa za klauzulę generalna (bez przymiotnika specyficzna). Po wtóre $\mathrm{w}$ orzecznictwie sądowym ${ }^{12}$, administracyjnym ${ }^{13}$ oraz $\mathrm{w}$ literaturze przed-

${ }^{4}$ Zob. art. 23 u.p.d.o.f. oraz art. 16 u.p.d.o.p.

5 Enumeratywny wykaz tych wydatków oraz okoliczności i warunki ich obliczania normuja odpowiednio art. 22 ust. 1aa - ust. 16 u.p.d.o.f.; art. 15 ust. 1aa - ust. 11 u.p.d.o.p. Szerzej zob. Bartosiewicz, Kubacki (2015).

${ }^{6}$ Interpretację taką potwierdza orzecznictwo zob. np. wyrok WSA w Lublinie z 21 listopada 2018 r., I SA/Lu 534/18, Lex nr 2597373; wyrok NSA w Warszawie z 13 listopada 2018 r., II FSK 3366/16, Lex nr 2595528.

7 Zob. wyrok NSA z 12 maja 2016 r., II FSK 837/14, CBOSA; wyrok WSA w Poznaniu z 26 czerwca 2012 r., SA/Po 216/12, CBOSA; wyrok WSA we Wrocławiu z 16 sierpnia 2010 r., I SA/Wr 678/10, CBOSA.

8 Zob. m.in. interpretacja indywidualna wydana przez Urząd Skarbowy Wrocław-Stare Miasto w 28 kwietnia 2004 r., PD III 423/540/04, <http://interpretacja-podatkowa.pl/interpretacja/ pokaz/4-podatek-dochodowy-od-osob-fizycznych/5-koszty-uzyskania-przychodow/5281-czlonek-zarzadu-koszty-uzyskania-przychodow-szkolenie-pracownicze.html> [dostęp: 8.02.2019]; interpretacja indywidualna Dyrektora Krajowej Informacji Skarbowej z 2 maja 2015 r., 0113-KDIPT2-1.4011.258.2018.1.KO, <https://sip.mf.gov.pl> [dostęp: 19.03.2019]; interpretacja indywidualna wydana przez Dyrektora Izby Skarbowej w Warszawie 27 stycznia 2009 r., IPPB1/415-1312/08-2/ EC, <https://www.ifirma.pl/blog/interpretacja-podatkowa-czy-zakup-okularow-korekcyjnych-jest-kosztem-firmy.html> [dostęp: 8.02.2019].

9 Borszowski (2010): 171, 206, 263-263, 284, 288, 301; Michalak (2006); Jastrowicz (2011): 59; Zieliński (2014): 284. Podobnie zob. Kleczkowski (2012): 23-36; Mikuła (2018).

10 Zob. np. wyrok NSA z 13 grudnia 2009 r., II FSK 1019/08, CBOSA; wyrok WSA w Rzeszowie z 26 sierpnia 2014 r., I SA/Rz 521/14, CBOSA.

11 Por. Dauter (2006): 344; Pikuła (2011).

12 Zob. np. wyrok WSA w Poznaniu z 26 czerwca 2012 r., SA/Po 216/12, CBOSA; wyrok NSA w Warszawie z 13 listopada 2018 r., II FSK 3194/16, Lex nr 2588096; wyrok WSA w Warszawie z 21 października 2014 r., SA/Wa 695/14, CBOSA.

13 Zob. interpretacja indywidualna Dyrektora Izby Skarbowej w Warszawie z 14 października 2015 r., IPPB1/4511-1035/15-2/AM, zmieniona interpretacjąindywidualną z 13 października 2016 r., 
miotu $^{14}$ można spotkać zupełnie przeciwstawne stanowiska wskazujące, że koszty podatkowe stanowią definicję legalną. Zdarzają się również wyroki ${ }^{15}$ oraz opracowania naukowe ${ }^{16}$, w których koszty uzyskania przychodów uznawane są jednocześnie za klauzulę generalną i legalną definicję. W literaturze przedmiotu można znaleźć jeszcze inne określenia dotyczace konstrukcji kosztów uzyskania przychodów. Niektórzy autorzy posługują się wyrażeniem prawnej formuły kosztu podatkowego ${ }^{17}$ bądź też normatywnej koncepcji kosztów uzyskania przychodów ${ }^{18}$.

Powyższa analiza orzecznictwa i piśmiennictwa wskazuje na to, że od wielu lat istnieje poważna niekonsekwencja w interpretowaniu niezwykle istotnego wyrażenia, jakim są koszty uzyskania przychodów, czyli pojęcia określającego zdarzenia pozwalające na ustalenie właściwego przedmiotu opodatkowania ${ }^{19}$. Wydaje się, że najważniejsza przyczyną powstających rozbieżności w ocenie tego, jaką konstrukcję prawną stanowią koszty podatkowe, są trudności związane z ustaleniem różnic teoretycznoprawnych pomiędzy:

- szacunkowym zwrotem nieostrym a klauzula generalną oraz

- pomiędzy klauzulą generalną a definicją legalną ${ }^{20}$.

Jeden zwrot prawny zakodowany na etapie stanowienia prawa w treści normy prawnej nie może być interpretowany przez różne podmioty stosujace prawo jednocześnie jako: zwrot niedookreślony, klauzula generalna i definicja prawna. Zjawisko takie jest bowiem sprzeczne z obowiązująca pozytywistyczną koncepcją racjonalnego ustawodawcy, w myśl której jest to idealny użytkownik języka, świadomy zastosowania każdego wyrazu, uzasadniający zastosowanie wszystkich konstrukcji składniowych, mający pełną wiedzę o rzeczywistości, którą modyfikuje swoimi poczynaniami ${ }^{21}$, oraz kierujący się spójnym systemem wartości i ocen ${ }^{22}$.

DD9.8220.2.204.2016.JPQ, <https://sip.mf.gov.pl> [dostęp: 19.03.2019]; zob. także np. interpretacja indywidualna Dyrektora KIS z 2 grudnia 2018 r., 0111-KDIB2-3.4010.348.2018.1.APA, <https:// interpretacje-podatkowe.org/koszty-uzyskania-przychodow/0111-kdib2-3-4010-348-2018-1-apa> [dostęp: 19.03.2019].

${ }^{14}$ Kowalska, Borszowski (2008): 7-10; (2009): 7-12; Borszowski (2008): 118-124; (2017a): 27, przyp. 43; (2017b): 71-80; Selera (2010); Bartosiewicz, Kubacki (2015); Małecki, Mazurkiewicz (2018).

${ }^{15}$ Zob. wyrok NSA oz. we Wrocławiu z 2 września 2002 r., I SA/Wr 1118/00, CBOSA.

${ }^{16}$ Taka dychotomiczna klasyfikacja omawianego pojęcia widoczna jest np. w tytule artykułu autorstwa Kleczkowskigo (2012): 23-36; zob. podobnie: Romańczuk, Pietrasiewicz, Skorupa (2006); Jastrowicz (2011).

${ }_{17}$ Zob. Gomułowicz (2016a).

${ }^{18}$ Por. Huchla (2014): 61-71. Przy czym podkreślić należy, że w przywołanej publikacji autor wskazuje jednak na to, że w przepisach normujących koszty uzyskania przychodów znajduje się legalna definicja tego pojęcia (zob. ibidem: 65). Por. Nykiel (2015): 365 n.

${ }^{19}$ Zob. art. 9 ust. 2 u.p.d.o.f.; art. 7 ust. 2 u.p.d.o.p.

${ }^{20}$ Por. Zieliński (2017): 258.

${ }^{21}$ Kłodowski (2012): 121.

${ }^{22}$ Pieniążek (2007): 108. 


\section{KLAUZULA GENERALNA JAKO ZWROT OCENNY NIEOSTRY}

W celu ustalenia właściwej kategoryzacji kosztów uzyskania przychodów zasadne wydaje się odwołanie do brzmienia przepisów rozporządzenia Prezesa Rady Ministrów o zasadach techniki prawodawczej oraz piśmiennictwa. W przywołanym akcie prawnym ustawodawca posłużył się wprawdzie terminem klauzula generalna, ale nie zdefiniował tego pojęcia. W przepisach wskazano jedynie, że zasadniczą funkcją klauzuli generalnej, podobnie jak i innych pojęć nieostrych, jest zapewnienie w razie potrzeby elastyczności tekstu aktu normatywnego ${ }^{23}$. Rozwiązanie takie wydaje się w pełni zasadne, gdyż definicje, cechy i funkcje klauzul generalnych jako kategorii prawnych stanowia jeden z najbardziej interesujacych przedmiotów badawczych jurysprudencji oraz dogmatyki z zakresu różnych gałęzi prawa ${ }^{24}$. Klauzula generalna jest bowiem jedną z najstarszych kategorii prawnych wykorzystywanych do konstruowania otwartych znaczeniowo norm prawnych. Charakterystyczną cechą tego nieostrego ocennego zwrotu prawnego jest to, że treść przepisów prawnych regulujących konkretną klauzulę generalną w sposób jednoznaczny wskazuje (nazywa) rodzaj dobra lub wartości pozaprawnej, które zgodnie z intencja prawodawcy ma być przez ten zwrot chronione $\mathrm{w}$ toku stosowania prawa. Do najbardziej znanych klauzul generalnych funkcjonujących $\mathrm{w}$ polskim systemie prawa należą m.in. takie zwroty prawne, jak: dobro wspólne, dobra wiara, dobre obyczaje, względy słuszności, rozsądek, zasady współżycia społecznego, ustalone zwyczaje, społeczno-gospodarcze przeznaczenie prawa, interes społeczny, interes publiczny, ważny interes indywidualny lub ważny interes podatnika, ważny interes gracza, a także bezpieczeństwo i porządek publiczny oraz bezpieczeństwo Rzeczypospolitej Polskiej. Odkodowanie zakresu znaczeniowego każdej prawidłowo sformułowanej pod względem językowym klauzuli generalnej odbywa się wyłacznie $\mathrm{w}$ procesie wykładni prawa $\mathrm{z}$ uwzględnieniem norm i ocen należących do obszaru pozaprawnego powszechnie w społeczeństwie akceptowanego ${ }^{25}$. Tę najważniejszą cechę klauzul generalnych potwierdza również jednolite w tej kwestii orzecznictwo $\mathrm{TK}^{26}$.

Wykładnia językowa pojęcia kosztów uzyskania przychodów unormowanego $\mathrm{w}$ przepisach obydwóch ustaw podatkowych nie pozwala na jasne i jednoznaczne wskazanie ani konkretnych dóbr, ani wartości pozaprawnych

${ }^{23}$ Zob. § 155 pkt 1 rozporządzenia Prezesa Rady Ministrów w sprawie „Zasad techniki prawodawczej”, t.jedn.: Dz. U. 2016, poz. 283 (dalej jako: z.t.p.).

${ }^{24} \mathrm{Na}$ temat cech i funkcji klauzul generalnych w systemie prawa zob. m.in.: Stelmachowski (1966); Czarzasty (1978); Pawełczyk (1984); Wójcik (1981), (1988); Safjan (1990); Zieliński (1992); (1997); Preussner-Zamorska (1997); Leszczyński (1986); (1995); (2001); Rott-Pietrzyk (2007); Szaraniec (2011); Hanusz (2016); Münnich (2017).

${ }_{25}$ Por. wyrok TK z 17 października 2000 r., SK 5/99, OTK 2000, nr 7, poz. 254. Zob. także: Maroń (2011): 90; Liżewski (2016): 192-194; Szot (2016): 292-296.

${ }^{26}$ Por. orzeczenie TK z 29 maja 1996 r., K 22/95, OTK 1996, nr 3, poz. 21; wyrok TK z 3 lipca 2001 r., K 3/01, OTK 2001, nr 5: 125; wyrok TK z 11 marca 2004 r., K 4/03, Dz. U. 2004, Nr 122, poz. 1288; wyrok TK z 11 marca 2015 r., P/14, Dz. U. 2015, poz. 369. 
należących do pozaprawnego obszaru aksjologicznego, społecznego czy ekonomicznego, które mogłyby in concreto wypełnić treść tego wyrażenia ${ }^{27}$. Podkreślić także należy, że w uzasadnieniach przeanalizowanych wyroków na ogół nie pojawia szersza teoretycznoprawna analiza rzeczywistej istoty samej klauzuli generalnej jako ocennego zwrotu prawnego, ani zakresu znaczeniowego pojęcia kosztów uzyskania przychodów jako zwrotu prawnego otwartego znaczeniowo. Zaznaczyć należy, że rozważania tego typu na ogół występują na przykład w wyrokach zapadających w sprawach związanych z unormowanymi w przepisach ordynacji podatkowej takimi klauzulami generalnymi, jak: ważny interes podatnika ${ }^{28} \mathrm{i}$ interes publiczny ${ }^{29}$.

Sumujac, stwierdzić należy, że unormowane w obydwóch ustawach podatkowych wyrażenie koszty uzyskania przychodów nie jest ani „swoista”, ani „nieswoistą klauzula generalną, a w związku z tym dokonywana w toku wykładni sądowej taka kwalifikacja jest błędna i niedopuszczalna.

\section{POJĘCIE DEFINICJI LEGALNEJ}

O ile przepisy przywołanego wyżej rozporządzenia w sprawie „Zasad techniki prawodawczej” w sposób niezwykle lapidarny normują kwestie związane ze stosowaniem w procesie legislacyjnym klauzuli generalnej, o tyle w przywołanym akcie prawnym bardzo szczegółowo uregulowane są warunki zastosowania w treści aktu prawnego innego instrumentu legislacyjno-technicznego, a mianowicie definicji legalnej. Zgodnie z treścią rozporządzenia w konkretnej ustawie lub innym akcie normatywnym może być sformułowana definicja danego określenia, jeżeli:

1) jest ono wieloznaczne;

2) jest nieostre, a jest pożądane ograniczenie jego nieostrości;

3) jego znaczenie nie jest powszechnie zrozumiałe;

${ }^{27}$ Za taką wartość o charakterze aksjologicznie (moralnie, etycznie) uniwersalna, czy nawet ekonomicznie nie można uznać - jak podaje np. Kleczkowski - konkretnego zakupu materiałów do produkcji dokonanego przez podatnika w związku z prowadzoną działalnością gospodarczą zob. Kleczkowski (2012): 31.

${ }^{28}$ Por. na temat wykładni ważnego interesu podatnika zob. m.in.: wyroki NSA: z 16 stycznia 2003 r., SA/Sz 945/01; z 8 lutego 2010 r., II FSK 1569/08; z 10 marca 2010 r., I FSK 31/08, CBOSA; a także wyroki NSA: z 22 lipca 2009 r., II FSK 71/09, Lex nr 555537; z 10 marca 2009 r., I FSK 31/08, Lex nr 537191; wyrok NSA z 28 kwietnia 2009 r., I FSK 263/08, Lex nr 513778, oraz wyrok WSA w Łodzi z 19 maja 2011 r., I SA/Łd 148/11, CBOSA; wyrok WSA we Wrocławiu z 3 listopada 2010 r., I SA/Wr 611/10, SIP Lex.

${ }^{29} \mathrm{Na}$ temat norm pozaprawnych, do których odsyła klauzula generalna interesu publicznego zob. np.: wyroki NSA: z 31 października 2000 r., III SA 660/99; z 30 maja 2001 r., III SA 830/00; 3 lipca 2007 r., I FSK 594/06; z 18 lutego 2016 r., II FSK 1569/08, CBOSA; a także wyrok WSA w Warszawie z 8 stycznia 2007 r., III SA/Wa 2904/2006, Monitor Podatkowy 2007, nr 11, s. 43-45; wyrok WSA w Rzeszowie z 27 maja 2010 r., I SA/Rz 210/10, CBOSA; wyrok WSA w Białymstoku z 6 lipca 2010 r., I SA/Bk 156/10, Lex nr 590320; wyrok WSA w Opolu z 8 lutego 2012 r., SA/Op 507/11, Lex nr 1116042; wyroki NSA: z 11 czerwca 2015 r., I SA/Kr 274/15, CBOSA; z 16 stycznia 2007 r., I FSK 477/06, ONSAiWSA 2008, nr 2(23), poz. 32. 
4) ze względu na dziedzinę regulowanych spraw istnieje potrzeba ustalenia jego nowego znaczenia ${ }^{30}$.

Przepisy rozporządzenia wskazują na możliwość posłużenia się w aktach prawnych dwoma rodzajami definicji legalnych, a mianowicie definicją klasyczną treściową oraz definicją nieklasyczną zakresowa. Pierwszą z nich charakteryzuje to, że w jej treści pojawiają się sformułowania typu „Określenie „a” oznacza b”, albo „Określenie „a” znaczy tyle co wyrażenie „b” lub jeżeli względy stylistyczne przemawiają za inną formą definicji, używa się zwrotu łączącego ,jest to" ${ }^{31}$.

Definicję zakresową (wyliczająca elementy składowe zakresu) formułuje się natomiast $\mathrm{w}$ jednym przepisie prawnym i obejmuje się nią cały zakres definiowanego pojęcia ${ }^{32}$. Jeżeli wyliczenie wszystkich elementów zakresu definiowanego pojęcia $\mathrm{w}$ jednym przepisie prawnym nie jest możliwe, $\mathrm{w}$ definicji wyraźnie zaznacza się, że tekst tej samej lub innej ustawy zawiera nadto elementy uzupełniające tę definicję, w szczególności przez użycie zwrotu: „... i inne wskazane w przepisach ...” ${ }^{33}$. Definicja zakresowa może mieć formułę zamkniętej lub otwartej. Ten drugi przypadek stosuje się, jeżeli nie jest możliwe sformułowanie definicji, o której mowa w $§ 153$ ust. 1 lub 2, można objaśnić znaczenie danego określenia przez przykładowe wyliczenie jego zakresu, wyraźnie wskazując przykładowy charakter wyliczenia przez posłużenie się zwrotem: „W szczególności” ${ }^{34}$.

Wykładnia językowa obecnej normatywnej formuły kosztów uzyskania przychodów wskazuje na to, że jest to bez watpienia definicja legalna. Pozostaje jedynie ustalenie tego, jaki jest to konkretnie rodzaj definicji.

Pomocna w tym procesie okazuje się literatura z zakresu teorii prawa w świetle jej ustaleń koszty uzyskania przychodów są modelową definicją materialną legalną intrajęzykowa, czyli taka, która pełni dwie funkcje. Po pierwsze, stwierdza istnienie przedmiotów (przedmiotu), którym przypisuje pewne właściwości. Po drugie, wskazuje, że przedmioty te noszą określoną nazwę. Za pomoca tego typu definicji ustawodawca legalizuje, czyli wprowadza do systemu prawnego określone pojęcia. Dodać należy, że budowa semantyczna definicji intrajęzykowych zawiera sformułowania typu „ustala się”; „określa się”; ,zalicza się”; ,jest to” oraz „,są to”. Definicję tego typu tworzyć może kilka rozbudowanych $\mathrm{zdañ}^{35}$. Analizowane w niniejszej publikacji przepisy ustaw podatkowych normujące konstrukcję kosztów uzyskania przychodów zawierają sformułowanie „są to" i jest ona uzupełniona o dwa zamknięte katalogi. Katalog pozytywny doprecyzowujący (definiujący) poszczególne rodzaje kosztów

${ }^{30}$ Zob. $\$ 146$ ust. 1 z.t.p.

31 Zob. pełny tekst rozporządzenia: $§ 151$ pkt 1 i pkt 2.

32 Zob. § 153 ust. 1 z.t.p.

33 Zob. $§ 153$ ust. 2 z.t.p.

${ }^{34}$ Zob. $\$ 153$ ust. 3 z.t.p.

35 Zob. szerzej: Malec (2000): 44-49. Zdaniem przywołanego autora, definicja legalna intrajęzykowa wyrażenia $W$ określa znaczenie, w jakim $W$ jest użyte przez prawodawcę w tekście prawnym $T$, charakteryzując desygnaty wyrażenia $W$. 
uzyskania przychodu ${ }^{36}$ oraz katalog negatywny wskazujący konkretne rodzaje wydatków, których w myśl ustawy nie można zaliczyć do wykazu kosztów uzyskania przychodów.

$\mathrm{W}$ piśmiennictwie podatkowym słusznie podkreśla się, że uzupełnienie definicji generalnej pojęcia kosztów uzyskania przychodów o dwa wskazane wyżej typy katalogów umożliwia podmiotom dokonującym interpretacji, rozpatrywanie każdej sytuacji faktycznej odrębnie, przy pełnym uwzględnieniu właściwych dla niej okoliczności. Zdarzyć się bowiem może, że wydatki, które u większości podatników stanowia koszty uzyskania przychodów, u konkretnego podatnika moga takiej kwalifikacji nie podlegać i vice versa ${ }^{37}$.

Przyjmując, że koszty uzyskania przychodów są definicją legalna, należy od razu zaznaczyć, że piśmiennictwo teoretycznoprawne wskazuje, iż w przypadku tego typu instytucji technicznolegislacyjnych podmiot dokonujaccy interpretacji przepisów nie może odejść od rezultatów wykładni językowej ${ }^{38}$. Zasada ta nie odnosi się natomiast do klauzul generalnych, które z uwagi na ich szatę językową i odwołanie do systemu pozaprawnego z reguły wymagaja zastosowania dyrektyw wykładni celowościowej lub funkcjonalnej.

\section{PRZYCZYNY BEĘDNEJ KWALIFIKACJI KOSZTÓW UZYSKANIA PRZYCHODÓW JAKO „SWOISTEJ KLAUZULI GENERALNEJ”}

Powstaje zatem pytanie, dlaczego normatywna formuła pojęcia kosztów uzyskania przychodów bywa, i to ewidentnie, coraz częściej błędnie kwalifikowana jako „swoista klauzula generalna”. Bez watpienia zgodnie z intencja prawodawcy w obecnie obowiązującej wersji definicji legalnej instytucji kosztów uzyskania przychodów położony został wyraźny akcent na to, aby za koszty uzyskania przychodów uznawane były wyłącznie te, które podatnik poniósł:

- w celu osiagnięcia przychodów lub

- w celu zachowania albo zabezpieczenia źródła przychodów, o ile nie należą one do katalogu wydatków negatywnych niekwalifikowanych jako koszty uzyskania przychodu.

Podkreślić należy, że przepisy normujace koszty podatkowe na przestrzeni niemal trzydziestu lat przechodziły dość znaczne zmiany legislacyjne, które następnie znajdowały odzwierciedlenie $\mathrm{w}$ kierunkach interpretacyjnych tego pojęcia ${ }^{39}$. Zarówno w orzecznictwie, jak i publikacjach podatkowych jako przesłanki wypełniające zakres znaczeniowy nieostrego normatywnego wyrażenia „w celu" najczęściej przywoływane są następujące okoliczności wskazujące na to, że:

\footnotetext{
36 Por. Brzeziński (2013): 67.

37 Zob. Bartosiewicz, Kubacki (2015) oraz Huchla (2014): 67.

38 Huchla (2014): 69, Zieliński (2017): 191.

39 Por. Huchla (2014): 67.
} 
1) poniesione przez podatnika koszty muszą być wiązane z osiagniętym przychodem ${ }^{40}$ i muszą mieć charakter definitywny ${ }^{41}$;

2) między poniesieniem kosztów a przychodem musi istnieć związek przyczynowo-skutkowy bezpośredni lub pośredni ${ }^{42}$;

3) związek ten musi być odpowiednio (rzetelnie) udokumentowany ${ }^{43}$.

Zarówno w orzecznictwie, jak i w piśmiennictwie owe niejasno sformułowane wyrażenie „w celu” z reguły uzupełnia się innymi niedookreślonymi zwrotami ocennymi pozanormatywnymi, takimi jak np.: racjonalność, zasadność i niezbędnośćc ${ }^{44}$. Przy czym w ostatnich kilku latach podmioty dokonujace interpretacji tego kluczowego dla definicji kosztów podatkowych wyrażenia, ustalając jego zakres znaczeniowy, ewidentnie główny akcent kładą na badanie racjonalności i nieracjonalności oraz rozsądku w działaniu podatnika. Podkreślić należy, że nie jest to nowa tendencja interpretacyjna. Orzeczenia sądowe wskazujące na tego typu kryterium ocenne pojawiały się bowiem już w połowie lat dziewięćdziesiątych ubiegłego wieku. Wydaje się jednak, że zarówno w orzecznictwie sądowym, jak i w interpretacjach organów podatkowych, a także w literaturze nurt ten przybiera na sile i coraz częściej zamiast badania „celowości” dokonywania wydatków, sądy i organy analizują okoliczności wskazujące np. na:

- racjonalne ${ }^{45}$ lub nieracjonalne działania podatnika ${ }^{46}$,

- racjonalność działania dla osiagnięcia przychodu ${ }^{47}$,

- racjonalność w dokonywaniu wydatków ${ }^{48}$,

${ }^{40}$ Por. wyroki NSA: z 18 sierpnia 2004 r., FSK 336/04, niepublik.; z 19 grudnia 2007 r., II FSK 1438/06; z 7 czerwca 2011 r., II FSK 462/11; 12 lutego 2012 r., II FSK 627/12; z 7 października 2014 r., II FSK 2436/12; z 13 kwietnia 2017 r., II FSK 791/15; z 17 maja 2017 r., II FSK 1056/15; z 19 maja 2017 r., II FSK 3009/15 i FSK 1187/15, CBOSA; a także wyrok WSA w Lublinie z 21 listopada 2018 r., I SA/Lu 534/18, Lex nr 2597373; wyrok NSA w Warszawie z 13 listopada 2018 r., II FSK 3194/16, CBOSA.

${ }^{41}$ Nykiel (2015): 365-366, oraz wyrok WSA w Białymstoku z 19 maja 2004 r., I SA/Bk 77/04, CBOSA.

${ }^{42}$ Zob. np.: wyrok NSA z 13 listopada 2018 r., II FSK 3194/16, Lex nr 2588096, oraz podobne tezy orzecznicze w wyrokach NSA w sprawach: II FSK 571/16, II FSK 911/16, II FSK 2609/15, II FSK 1438/06, II FSK 1755/06, II FSK 1405/07, II FSK 418/09, II FSK 462/11, II FSK 1484/15, CBOSA. Por. wyrok WSA w Białymstoku z 14 listopada 2018 r., I SA/Bk 300/18, Lex nr 2585060; wyrok WSA w Poznaniu z 26 czerwca 2012 r., SA/Po 216/12, CBOSA; wyrok WSA w Lublinie z 21 listopada 2018 r., I SA/Lu 534/18, Lex nr 2597373; por. Mariański (2006): 13: Nykiel (2015): 366 n.; Gomułowicz (2016): 34-35.

${ }^{43}$ Zob. wyrok NSA z 2 grudnia 1993 r., SA/Po 2020/93, CBOSA; wyrok NSA z 9 września 1994 r., III SA 30/94, CBOSA; wyrok WSA w Rzeszowie z 26 sierpnia 2014 r., I SA/Rz 521/14, CBOSA; wyrok WSA w Lublinie z 21 listopada 2018 r., I SA/Lu 534/18, Lex nr 2597373. Por. także wyrok NSA z 13 listopada 2018 r., II FSK 3194/16, Lex nr 2588096; Nykiel (2015): 366 n.

${ }^{44}$ Por. Dauter, Gomułowicz (2008): 61.

${ }^{45}$ Por. wyrok NSA z 9 września 1994 r., III SA 30/94, Monitor Podatkowy 1995, nr 1, s. 18; wyrok WSA w Poznaniu z 26 czerwca 2012 r., SA/Po 216/12, CBOSA.

${ }^{46}$ Por. wyrok NSA z 3 grudnia 2009 r., III FSJ 1019/08, CBOSA; interpretacja indywidualna wydana przez Dyrektora Izby Skarbowej w Warszawie 12 kwietnia 2012 r., IPPB3/423-35/12-2/GJ, $<$ https://www.rp.pl/Podatek-dochodowy/303239998-Koszty-uzyskania-przychodu-fiskus-nie-moze-kwestionowac-racjonalnosci-wydatkow.html> [dostęp: 15.03.2019].

${ }_{47}$ Zob. wyrok WSA we Wrocławiu z 28 stycznia 2011 r., I SA/Wr 229/10, CBOSA.

${ }_{48}$ Zob. wyrok WSA w Warszawie w wyroku z 23 lipca 2004 r., III 949/03, CBOSA, oraz wyrok WSA w Olsztynie w wyroku z 21 sierpnia 2008 r., I SA/Ol 273/08, CBOSA; interpretacja indywi- 
- nieracjonalność działania z ekonomicznego punktu widzenia ${ }^{49}$,

- przestrzeganie zasad racjonalnego rozumowania ${ }^{50}$,

- kierowanie się rozsądkiem w odejmowaniu wydatków ${ }^{51}$,

- racjonalność i gospodarcze uzasadnienie wydatki związane z działalnością gospodarczą ${ }^{52}$.

Podnieść należy, że zarówno kryterium racjonalności, jak i rozsądku w działaniu gospodarczym nie są unormowane w przepisach regulujacych treść kosztów uzyskania przychodów ${ }^{53}$. Są to typowe zwroty szacunkowe o proweniencji ekonomiczno-gospodarczej, których celem jest umożliwienie dokonania indywidualnej oceny zachowania podatnika w konkretnej sytuacji faktycznej. Wyrażania te należą do obszaru racjonalnych kryteriów ekonomicznych charakterystycznych dla przepisów antyabuzywnych związanych z instytucja nadużycia prawa, a przede wszystkim lub klauzulą ogólną przeciwko unikaniu opodatkowania. Zwroty szacunkowe nawiązujące do kryteriów rozsądkowych i racjonalnych, o czym ani w judykaturze, ani w polskim piśmiennictwie podatkowym w ogóle się nie wspomina, są charakterystycznym elementem składowym coraz bardzie popularnej w prawie prywatnym cywilistycznej klauzuli generalnej rozsądku ${ }^{54}$.

Analiza wyroków i interpretacji podatkowych dotyczacych kosztów uzyskania przychodów, w których główny nacisk położony został na kwestie związane z racjonalnością działania podatnika prowadzi do następującej konkluzji. Obowiąująca definicja kosztów uzyskania przychodów jest coraz mniej adekwatna do pojawiajacych się nowych form i powiązań ekonomicznych umożliwiajacych podatnikom szybki i wysokodochodowy obrót gospodarczy oraz agresywną optymalizację podatkową. W związku z tym podmioty dokonujące interpretacji uznaja, że ową literalną treść przepisów wskazująca na to, że wydatek winien być poniesiony - „w celu osiagnięcia przychodów lub zachowania albo zabezpieczenia źródła przychodów” - należy interpretować za pomoca

dualna wydana przez Dyrektora Krajowej Informacji skarbowej 13 sierpnia 2018 r., 0114-KDIP2-2.4010.257.2018.1.SO, <https://sip.mf.gov.pl/faces/views/szczegoly/szczegoly-interpretacji-indywidualnej.xhtml?dokumentId=537837\&poziomDostepu=PUB\&indexAccordionPanel=-1\#tresc $>$ [dostęp: 15.05.2019].

${ }^{49}$ Zob. wyrok WSA w Lublinie z 29 października 2004 r., I SA/Lu 234/04, CBOSA.

${ }^{50}$ Zob. por. wyroki NSA: z 3 grudnia 2009 r., III FSJ 1019/08; z 7 czerwca 2011 r., II FSK 462/11; z 23 października 2012 r., II FSK 946/11; z 27 lutego 2013 r., II FSK 1391/11; z 19 sierpnia 2016 r., II FSK 1923/14, CBOSA.

51 Zob. np. wyroki NSA: z 9 lutego 2001 r., I SA/Gd 1367/98; z 17 lipca 2003 r., SA/Bd 1818/01, CBOSA.

${ }^{52}$ Zob. interpretacja indywidualna wydana przez Dyrektora Izby Skarbowej w Warszawie w dniu 27 października 2010 r., IPPB3/423-500/10-2/JG, <https://e-prawnik.pl/interpretacje-podatkowe/ippb3423-50010-2jg.html> [dostęp: 15.05.2019]; interpretacja indywidualna wydana przez Dyrektora Krajowej Informacji Skarbowej 13 sierpnia 2018 r., 0114-KDIP2-2.4010.257.2018.1.SO, $<$ https://www.podatki.biz/artykuly/koszty-uzyskania-przychodow-wydatki-refakturowane-przez-podmoty-wspolpracujace_14_39372.htm> [dostęp: 15.05.2019]. Por. wyrok WSA w Lublinie z 10 sierpnia 2017 r., I SA/Lu 380/17, CBOSA.

${ }^{53}$ Fakt ten, czyli brak unormowania w przepisach o kosztach uzyskania przychodu kryteriów ekonomicznych stanowiących treść zwrotów szacunkowych, jest zresztą w orzecznictwie podnoszony, zob. np. WSA w Poznaniu z 26 czerwca 2012 r., SA/Po 216/12, CBOSA.

${ }^{54}$ Münnich (2019): 129-139. 
jeszcze bardziej otwartych znaczeniowo kryteriów odwołujących się do obszarów racjonalnego, rozsądnego działania podatnika oraz działania uzasadnionego ekonomicznie i gospodarczo. Pojęcia tego typu pozwalają bowiem sądom i organom podatkowym w sposób bardziej elastyczny interpretować przepisy $\mathrm{w}$ danym stanie faktycznym.

Podkreślić należy, że szczególnie w orzecznictwie sądowym pojęcie racjonalnego lub rozsądnego działania przedsiębiorcy rozumiane jest literalnie (słownikowo) jako działanie podejmowane na podstawie takiego stanu wiedzy, jaki posiadał podatnik $\mathrm{w}$ momencie ponoszenia wydatku ${ }^{55}$, uwzględniajace duże prawdopodobieństwo wystapienia przychodu ${ }^{56}$ oraz sytuację finansowa podmiotu gospodarczego w kontekście jego realnych potrzeb ${ }^{57}$.

\section{KONKLUZJE}

Jak wskazano w niniejszym artykule, koszty uzyskania przychodów nie sa ani „swoistą”, ani „nieswoistą klauzula generalną”, nie są także zwrotem niedookreślonym. Obowiązująca obecnie normatywna formuła instytucji kosztów uzyskania przychodów pozwalająca na zmniejszenie dochodu, a tym samym finalne obniżenie wysokości podatku, stanowi definicję legalna. Jest to definicja materialna o charakterze intrajęzykowym zawierająca zwrot nieostry znaczeniowo „w celu osiagnięcia przychodów lub zachowania albo zabezpieczenia źródła przychodów", którego odkodowanie w obecnych realiach gospodarczych i ekonomicznych wymaga odwołania się do pojęć z systemu pozaprawnego, takich jak: gospodarczo uzasadnione działanie podatnika; rozsądne lub nierozsądne; racjonalne bądź nieracjonalne dokonywanie wydatków, prowadzenie działalności itd. Podkreślić należy, że sam fakt, iż organy podatkowe i wojewódzkie sądy administracyjne na etapie stosowania prawa podatkowego odwołują się do tych kryteriów, absolutnie nie pozawala na określanie instytucji kosztów uzyskania przychodów mianem klauzuli generalnej, gdyż szata językowa przepisów normujących tę instytucję nie spełnia wymagań ustalonych w piśmiennictwie teoretycznoprawnym i orzecznictwie TK właściwych dla tej kategorii prawnej.

Klasyfikacja kosztów uzyskaniu przychodów mogłaby jednak ulec zmianie, gdyby ustawodawca dokonał zmian legislacyjnych w treści normatywnej ustaw podatkowych normujących formułę prawną tego pojęcia i w miejsce przywoła-

${ }^{55}$ Klebieko (2012) oraz wyrok WSA z 23 czerwca 2009 r., III SA/Wa 460/09, CBOSA.

${ }^{56}$ Zob. wyroki NSA: z 12 maja 1999 r., I SA/Wr 482/97, niepublik; 14 sierpnia 2003 r., SA/Bd 1627/03, CBOSA, a także wyrok WSA w Olsztynie z 21 grudnia 2007 r., I SA/Ol 534/07, Lex nr 399547. Zob. także Gomułowicz (2016): 37-39.

57 Zob. wyrok NSA z 17 lipca 2003 r., SA/Bd 1818/03, CBOSA. Podobnie NSA orzekł w starszym, niepublikowanym wyroku z 13 marca 1998 r., I SA/Lu 230/97, w którym wskazał, że kosztami uzyskania przychodów są wszelkie racjonalne i gospodarczo uzasadnione wydatki związane z prowadzoną działalnością gospodarczą, których celem jest osiagnięcie, zabezpieczenie i zachowanie źródła przychodów. 
nego wyżej zwrotu nieostrego, wprowadził i nazwał imiennie konkretny rodzaj dobra lub wartości, które klauzula miałaby chronić (np. rozsądne działanie podatnika). Podnieść jednak należy, że taka zmiana legislacyjna oznaczałaby konieczność usunięcia z ustaw podatkowych uzupełniających obecną definicję kosztów uzyskania przychodów, katalogów wydatków niepotrącalnych. Wydaje się, że w obecnych warunkach ekonomiczno-gospodarczych taka rewolucja szaty językowej obowiązujących przepisów normujących koszty podatkowe nie jest ani zasadna, ani możliwa.

\section{Monika Münnich}

Katolicki Uniwersytet Lubelski Jana Pawta II

mmunnich@kul.pl

https://orcid.org/0000-0002-9250-5748

Bartosiewicz, A., Kubacki, R. (2015). PIT. Komentarz. Lex/el.

Borszowski, P. (2008). Racjonalność i celowość w nowej definicji kosztów podatkowych - glosa do wyroku Naczelnego Sądu Administracyjnego z 18.11.2005 r. (II FSK 182/2005). Glosa 2: $118-124$.

Borszowski, P. (2010). Działalność gospodarcza w konstrukcji prawnej podatku. Warszawa.

Borszowski, P. (2017a). Określenia nieostre i klauzule generalne w prawie podatkowym. Warszawa.

Borszowski, P. (2017b). Koszty uzyskania przychodów - pomiędzy elastycznością a definiowaniem, [w:] P. Mrkývka, D. Czudek, J. Valdhans (red.), Dny práva 2016 - Days of law 2016. Č́st 2, Rekodifikace daní z př́ijmů: (90 let od Englišovy danové reformy). Brno: 71-80.

Brzeziński, B. (2013). Wykładnia prawa podatkowego. Gdańsk.

Czarzasty, J. (1978). Przyczynek do problematyki klauzul generalnych. Państwo i Prawo 33(5): $83-92$.

Dauter, B. (2006). Komentarz do art. 15, [w:] L. Błystak, B. Dauter, B. Gruszczyński, B. Hnatiuk, H. Łysikowska, E. Madej, A. Mudrecki, M. Niezgódka-Medek, R. Pęk, K. Wujek, J. Zubrzycki, Podatek dochodowy od osób prawnych. Komentarz 2006. Wrocław: 346-347.

Dauter, B., Gomułowicz, A. (2008). Koszt podatkowy. Aspekt teoretyczny i orzeczniczy. Warszawa.

Gomułowicz, A. (2016). Prawna formuła kosztu podatkowego. Warszawa.

Hanusz, A. (2016). Klauzule generalne w ordynacji podatkowej. Państwo i Prawo 61(8): 3-15.

Huchla, A. (2014). Kształtowanie się kosztów uzyskania przychodów przedsiębiorcy w podatku dochodowym od osób prawnych, [w:] P. Borszowski, A. Huchla (red.), Podatkowy slalom przedsiębiorcy. Wrocław: 61-71. [Online] < http://www.bibliotekacyfrowa.pl/Content/46547/05_Huchla_Andrzej.pdf> [dostęp: 14.05. 2019].

Jastrowicz, M. (2011). Ciężar dowodu w zakresie kosztów uzyskania przychodów w podatku dochodowym od osób prawnych. Studia Finansowoprawne 2: 59-67. [Online] <http://www.bibliotekacyfrowa.pl/Content/38906/007.pdf> [dostęp: 8.02.2019].

Kleczkowski, L. (2012). Definicja kosztów uzyskania przychodów jako klauzula generalna Kwartalnik Prawa Podatkowego 4: 23-36.

Klebieko, P. (2012). Celowości i racjonalność ponoszenia kosztów w podatku dochodowym od osób prawnych a swoboda decyzji gospodarczej przedsiębiorcy. <https://repozytorium.amu.edu.pl/ bitstream/10593/13554/1/09_KLEBIEKO.pdf> [dostęp: 8.02.2019].

Kłodowski, M. (2012). Pleonazmy i analityzmy - wrażenia redundantne pragmatycznie w języku prawnym, [w:] A. Niewiadomski, E. Sztymelska (red.), Język współczesnego prawa. Warszawa: $121-132$.

Kowalska, M., Borszowski, P. (2008). Racjonalność a pozorność w definicji kosztów podatkowych. Prawo i Podatki 4(10): 7-10.

Kowalska, M., Borszowski, P. (2009). Podejmowanie działalności gospodarczej a definicja kosztów podatkowych. Prawo i Podatki 5(2): 7-12.

Leszczyński, L. (1986). Klauzule generalne w stosowaniu prawa. Lublin. 
Leszczyński, L. (1995). Właściwości posługiwania się klauzulami generalnymi prawie polskim. Perspektywa zmian trendu. Kwartalnik Prawa Publicznego 3: 289-307.

Leszczyński, L. (2000). Tworzenie generalnych klauzul odsyłających. Lublin.

Leszczyński, L. (2001). Stosowanie generalnych klauzul odsyłających. Kraków.

Liżewski, B. (2016). Klauzule generalne i ich funkcje w Europejskiej Konwencji Praw Człowieka. Annales Universitatis Mariae Curie-Skłodowska Lublin-Polonia 63 (Sectio G 2): 192-194.

Malec, A. (2000). Zarys teorii definicji prawniczej. Warszawa.

Małecki, P., Mazurkiewicz, M. (2018). CIT. Komentarz. Podatki i rachunkowość. Warszawa: Lex/el.

Mariański, A. (2006). Brak podstaw do stosowania cywilnoprawnego pojęcia związku przyczynowo-skutkowego jako przesłanki uznania kosztu podatkowego. Przegląd Podatkowy 6: 13- 17.

Maroń, G. (2011). Zasady prawa. Pojmowanie i typologie a rola w wykładni prawa i orzecznictwie konstytucyjnym. Poznań.

Michalak, D. (2006). Pojęcie kosztu uzyskania przychodu w orzecznictwie sądów administracyjnych. <http://www.money.pl/podatki/ip/cit/pojecie-kosztu-uzyskania-przychodu-w-orzecznictwie-sadow-administracyjnych/> [dostęp: 8.02.2019].

Mikuła, P. (2018). Zagraniczny podatek od towarów i usług jako przychód i koszt podatkowy. $<$ https://www.russellbedford.pl/o-nas/rb-biuletyn/item/1061-zagraniczny-podatek-od-towarow-i-uslug-jako-przychod-i-koszt-podatkowy.html> [dostęp: 12.03.2019].

Münnich, M. (2017). Nieostre zwroty ocenne w polskim prawie podatkowym. Lublin.

Münnich, M. (2019). Elementy cywilistycznej klauzuli generalnej rozsądku w polskim prawie podatkowym podatkowym, [w:] A. Kaźmierczak, A. Franczak, Prawo podatkowe w systemie prawa. Międzygałęziowe związki norm i instytucji prawnych. Warszawa: 129-139.

Nykiel, W. (2015). Komentarz do art. 15 ust. 1, [w:] M. Bogucka-Felczak, T. Kardach, E. Klimek, J. Kordal, Z. Kukulski, A. Mariański (red.), T. Miłek, W. Nykiel (red.), D. Strzelec, M. Turzyński, M. Wilk, Komentarz do ustawy o podatku dochodowym od osób prawnych. Gdańsk: 365-409.

Pawełczyk, M. (1984). Uwagi o odsyłającym charakterze klauzul generalnych. Studia Iuridica Silesiana Katowice 9: 81-89.

Pieniążek, A. (2007). Norma prawna - przepis prawny - akt normatywny, [w:] A. Korybski, L. Leszczyński, A. Pieniążek, Wstęp do prawoznawstwa. Lublin: 91-118.

Pikuła, M. (2011). Koszty uzyskania przychodów w świetle orzecznictwa sądów administracyjnych - wybrane problemy, [w:] B. Brzeziński, J.P. Tarno (red.), Sądowa kontrola administracji w sprawach podatkowych. IV letnie warsztaty doktoranckie Łódź 30 czerwca -2 lipca 2010 r. [Online]. Lex/el.

Preussner-Zamorska, J. (1997). Problematyka funkcjonowania klauzul generalnych na tle ustawy o zwalczaniu nieuczciwej konkurencji. Kwartalnik Prawa Publicznego 1: 97-115.

Romańczuk, M., Pietrasiewicz, W., Skorupa, P. (2006). Koszty uzyskania przychodu - wybrane aspekty. Monitor Podatkowy 10. <https://czasopisma.beck.pl/monitor-podatkowy/artykul/ koszty-uzyskania-przychodow-wybrane-aspekty/> [dostęp: 12.03. 2019].

Rott-Pietrzyk, E. (2007). Klauzula generalna rozsądku w prawie prywatnym. Warszawa.

Safjan, M. (1990). Klauzule generalne w prawie cywilnym. Przyczynek do dyskusji. Państwo i Prawo 45(10): 49-67.

Safjan, M. (1997). Klauzule generalne w nowym porządku konstytucyjnym. Państwo i Prawo 52(11/12): 134-147.

Selera, P. (2010). Międzynarodowe a unijne prawo podatkowe w kontekście opodatkowania zysków przedsiębiorstw. Lex/el.

Stelmachowski, A. (1966). Klauzule generalne w prawie cywilnym. Państwo i Prawo 21(3): 470-483.

Szaraniec, M. (2011). Klauzula interesu publicznego i określenia nieostre - próba wyodrębnienia tych pojęć na gruncie ustawy o działalności ubezpieczeniowej, [w:] B. Gnela (red.), Ubezpieczenia gospodarcze. Wybrane zagadnienia prawne. Warszawa: 239-254.

Szot, A. (2016). Klauzula generalna jako ponadgałęziowa konstrukcja systemu prawa. Annales Universitatis Mariae Curie-Skłodowska Lublin-Polonia 63 (Sectio G, 2): 292-296.

Wójcik, K. (1981). Z problematyki klauzul generalnych prawa cywilnego. Studia Prawno-Ekonomiczne 27: 79-92.

Wójcik, K. (1988). Klauzule generalne jako zwroty wieloznaczne i oceny. Studia Prawno-Ekonomiczne 41: 36-61.

Zieliński, M. (2017). Wykładnia prawa. Zasady - reguły - wskazówki. Warszawa. 
Zieliński, R. (2014). Koszty uzyskania przychodów z działalności gospodarczej osób fizycznych jako bariera rozwoju przedsiębiorców w Polsce - wybrane problemy. Krytyka Prawa 5: 281-300.

Zieliński, T. (1992). Klauzule generalne w demokratycznym państwie prawnym. Studia Iuridica 23: $195-210$.

\author{
THE COSTS OF OBTAINING REVENUE IN INCOME TAXES \\ FROM INDIVIDUALS AND CORPORATE ENTITIES \\ - A SPECIFIC GENERAL CLAUSE OR LEGAL DEFINITION?
}

\title{
Summary
}

For many years, the costs of obtaining revenue, regulated in the acts on personal income tax and corporate income tax, in numerous judgments of both provincial administrative courts and the Supreme Administrative Court, as well as in administrative decisions of tax authorities and tax literature, are referred to as a 'specific general clause'. At the same time, the title institution of tax costs is sometimes referred to as a legal definition in both the judicature and scientific literature. The aim of the article is to clearly determine to which legal category this extremely important technical element of the construction of both income taxes in Poland belongs. One legal term, which is encoded at the stage of making law in the wording of a legal norm, cannot be interpreted by various entities applying the law at the same time as: a non-specified phrase, a general clause and a legal definition.

Keywords: tax; costs of obtaining revenue; general clause; legal definition 
